\title{
Orexin Affects Dorsal Root Ganglion Neurons: A Mechanism for Regulating the Spinal Nociceptive Processing
}

\author{
J.-A. YAN ${ }^{1} *$, L. GE ${ }^{2} *$ W. HUANG ${ }^{3}$, B. SONG ${ }^{1}$, X.-W. CHEN ${ }^{4}$, Z.-P. YU ${ }^{4}$ \\ * These authors contributed equally to this work \\ ${ }^{1}$ Urological Research Institute of PLA, Southwest Hospital, Third Military Medical University, \\ ${ }^{2}$ Department of Dermatology, Southwest Hospital, Third Military Medical University, ${ }^{3}$ School of \\ Basic Medicine, Third Military Medical University and ${ }^{4}$ Department of Occupational Health, Third \\ Military Medical University, Chongqing, China
}

Received April 11, 2008

Accepted June 18, 2008

\begin{abstract}
Summary
Orexins (orexin A and B) are initially known to be a hypothalamic peptide critical for feeding and normal wakefulness. In addition, emerging evidence from behavioral tests suggests that orexins are also involved in the regulation of nociceptive processing, suggesting a novel potential therapeutic approach for pain treatment. Both spinal and supraspinal mechanisms appear to contribute to the role of orexin in nociception. In the spinal cord, dorsal root ganglion (DRG) neurons are primary afferent neurons that transmit peripheral stimuli to the pain-processing areas. Morphological results show that both orexin A and orexin1 receptor are distributed in DRG neurons. Moreover, by using whole-cell patch-clamp recordings and calcium imaging measurements we found that orexin A induced excitability and intracellular calcium concentration elevation in the isolated rat DRG neurons, which was mainly dependent on the activation of spinal orexin-1 receptor. Based on these findings, we propose a hypothesis that the direct effect of orexin A on DRG neurons would represent a possible mechanism for the orexinergic modulation of spinal nociceptive transmission.
\end{abstract}

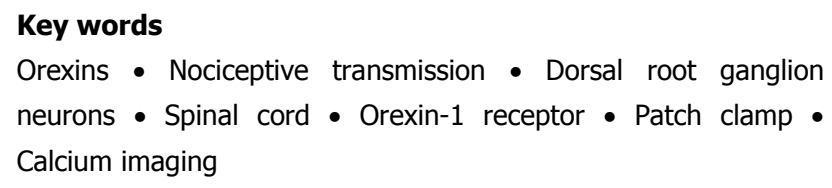

\section{Corresponding authors}

Xiao-wei Chen, Zheng-ping Yu, Department of Occupational Health, Third Military Medical University, Chongqing 400038, China. Fax: +862368752290. E-mail: shxiaowei@yahoo.com (X.-W. Chen); yuzping@yahoo.com (Z.-P. Yu)
Orexins are a pair of hypothalamic peptides (orexin A and B) implicated in the regulation of feeding, neuroendocrine homeostasis, drug addiction, autonomic functions and the sleep-wake behavior (Ferguson and Samson 2003, Sakurai 2007, Ohno and Sakurai 2008). Orexins act via two subtypes of G-protein coupled receptors, orexin-1 receptor and orexin-2 receptor, which are expressed in multiple brain regions and peripheral tissues (Voisin et al. 2003, Korczynski et al. 2006). Orexin-1 receptor displays higher affinity for orexin A, whereas orexin-2 receptor exhibits equal affinity for both peptides (Sakurai et al. 1998). At the cellular level, it has been shown that the main responses to the orexin receptor activation in various cells include $\mathrm{Ca}^{2+}$ elevation and increased electrical activity (Kukkonen et al. 2002).

In addition to the above functions, several lines of evidence suggest that orexin has a potential role in the modulation of nociceptive transmission. Orexin receptors are moderately expressed in the periaqueductal gray, a region involved in pain processing (Willis and Westlund 1997, Marcus et al. 2001). Orexin-containing neurons send strong projections to lamina I of the spinal cord that are important for nocicepive pathways (van den Pol 1999). Both orexin A and orexin B are distributed throughout the spinal cord and orexin fibers are concentrated in lamina I of the dorsal horn and in lamina $X$ surrounding the central canal (Date et al. 2000). Orexin-1 receptor is localized on C-fibers in the spinal cord (Hervieu et al. 2001). On the other hand, emerging 

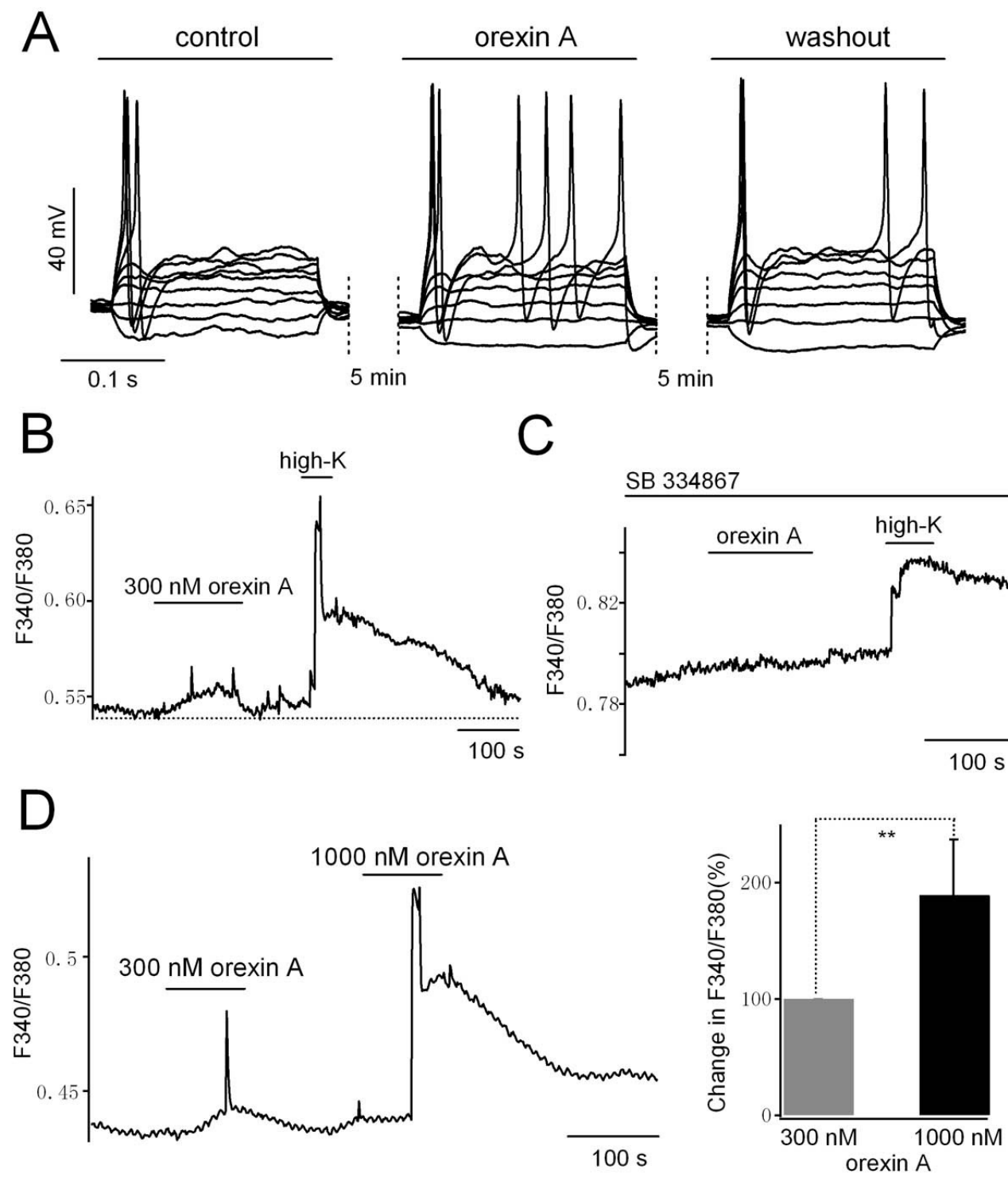

Fig. 1. Effects of orexin $A$ on the freshly isolated DRG neurons. A. Application of $300 \mathrm{nM}$ orexin $A$ increased the number of action potentials evoked by a series of current pulses of $-20 \mathrm{pA}$ to $+140 \mathrm{pA}$ (control, $3 \pm 1$ events; orexin $A, 8 \pm 3$ events) $(n=7 ; p<0.01)$. Single DRG neurons were freshly isolated from adult male Sprague-Dawley rats using enzymatic treatment as described elsewhere (Huang and Neher 1996). B. Application of $300 \mathrm{nM}$ orexin A significantly induced $\left[\mathrm{Ca}^{2+}\right]_{i}$ elevation $(n=6 ; p<0.01)$. High $\mathrm{K}^{+}$solution was applied as a positive control. C. Orexin A did not induce a calcium response in the presence of the selective orexin-1 receptor antagonist, SB 334867 $(1 \mu \mathrm{M})(\mathrm{n}=3)$. In contrast, high $\mathrm{K}^{+}$solution still increased $\left[\mathrm{Ca}^{2+}\right]_{\mathrm{i}}$ under this condition. $\mathbf{D}$. The calcium response to $300 \mathrm{nM}$ orexin $\mathrm{A}$ was significantly weaker than that to $1000 \mathrm{nM}$ orexin $\mathrm{A}$. Bar graph summarizes the normalized changes in F340/F380 ratio (300 nM orexin $A$, $0.042 \pm 0.009$ arbitrary units; $1000 \mathrm{nM}$ orexin $\mathrm{A}, 0.078 \pm 0.011$ arbitrary units; $\mathrm{n}=5)$. $* * \mathrm{p}<0.01$.

data from behavioral tests have confirmed the involvement of orexin system in nociceptive sensation. Orexin A produced analgesic effects in hot-plate test and formalin test (Bingham et al. 2001, Yamamoto et al. 2002). Subsequently, the analgesic effects of orexins have been studied extensively in various types of nociceptive models, such as postoperative pain (Cheng et al. 2003), neuropathic pain (Yamamoto et al. 2003b, Suyama et al. 2004), carrageenan test (Yamamoto et al. 2003a). In most studies, orexins showed antinociceptive effects on these types of pains (Mobarakeh et al. 2005a,b).
It has been demonstrated that both spinal and supraspinal mechanisms contribute to the antinociceptive effects of orexins (Bingham et al. 2001, Yamamoto et al. 2002). This is consistent with the localization of orexin-1 receptor in nociceptive regions of the spinal cord and the brain (Trivedi et al. 1998, Hervieu et al. 2001). It is also supported by the behavioral and pharmacological results demonstrating that administration of orexins into the spinal cord and related brain areas has analgesic effects (Mobarakeh et al. 2005b). However, in this article our attention was attracted by the question which sites in the 
spinal cord would be the targets of orexin action in the nociceptive transmission. Fibers containing orexin densely project to the superficial dorsal horn of the spinal cord (van den Pol 1999, Bingham et al. 2001), indicating the involvement of this site. In line with this, the electrophysiological results show that orexin B has direct excitatory effects on certain superficial dorsal horn neurons (Grudt et al. 2002).

In addition to the superficial dorsal horn, we also hypothesize that dorsal root ganglion (DRG) neurons are the targets of orexins responsible for the regulation of spinal nociceptive transmission. It has long been known that DRG neurons are primary afferent neurons that transmit information from peripheral stimuli to the painprocessing centers (Zhang and Bao 2006). Morphological evidence has shown that both orexin A and orexin-1 receptor are distributed in DRG neurons (Bingham et al. 2001). To investigate whether orexin would directly excite the DRG neurons, we performed a preliminary experiment by using the whole-cell patch clamp recording and Fura-2 $\mathrm{Ca}^{2+}$ imaging. In freshly isolated rat DRG neurons, bursts of action potentials were evoked by depolarizing current pulses under current clamp conditions. Application of orexin A significantly increased the number of the evoked action potentials (Fig. 1A), suggesting an excitatory effect on the DRG neurons. For intracellular $\mathrm{Ca}^{2+}$ imaging, the isolated DRG neurons on coverslips were loaded for $30 \mathrm{~min}$ with $1 \mu \mathrm{M}$ Fura-2 AM (Invitrogen, Carlsbad, CA, USA) at room temperature $\quad\left(22-24{ }^{\circ} \mathrm{C}\right) . \quad$ Fura-2 fluorescence measurements were performed as described previously (Zhang and Zhou 2002). As shown in Figures 1B and 1D, orexin A produced an elevation of intracellular calcium concentration $\left(\left[\mathrm{Ca}^{2+}\right]_{\mathrm{i}}\right)$ in DRG neurons in a dosedependent manner. However, in the presence of SB 334867 (the selective orexin-1 receptor antagonist) (Fig. 1C), orexin-induced calcium response was completely blocked, indicating a role of orexin-1 receptor in mediating the effect of orexin A on DRG neurons. Taken together, these results from electrophysiological recordings and imaging experiments support our hypothesis that orexin-induced excitability and intracellular calcium response in DRG neurons may be involved in its regulation of spinal nociceptive processing, which is mainly dependent on the activation of spinal orexin-1 receptor.

Up to now, much attention has been paid to the identification of the mechanisms responsible for the actions of orexin in varying cellular populations. One general accepted model suggests that the activation of $\mathrm{G}_{\mathrm{q}}$ by the binding of orexin to the orexin receptors triggers the phospholipase $\mathrm{C}$ and protein kinase signaling pathways, which subsequently leads to the enhancement of a nonselective cationic conductance and inhibition of a potassium current. This pathway would then mediate the excitatory effect caused by orexin (Yang et al. 2003). In addition, either extracellular $\mathrm{Ca}^{2+}$ influx or intracellular $\mathrm{Ca}^{2+}$ release contributes to the orexin-induced $\left[\mathrm{Ca}^{2+}\right]_{\mathrm{i}}$ increase in various cells (Xia et al. 2005). Therefore, further studies are needed to investigate the possible mechanisms underlying the responses to orexin which we observed in the DRG neurons.

In conclusion, based on the previous morphological finding (Bingham et al. 2001) and the present functional studies, we would like to suggest that the orexinergic projections to DRG neurons might provide a possible pathway for orexin modulation of pain information transmission, which suggests a new potential therapeutic target to treat the pain. However, further in vitro and in vivo studies are necessary to clarify how the orexin-DRG pathway is involved in the nociceptive sensory processes.

\section{Conflict of Interest}

There is no conflict of interest.

\section{References}

BINGHAM S, DAVEY PT, BABBS AJ, IRVING EA, SAMMONS MJ, WYLES M, JEFFREY P, CUTLER L, RIBA I, JOHNS A, PORTER RA, UPTON N, HUNTER AJ, PARSONS AA: Orexin-A, an hypothalamic peptide with analgesic properties. Pain 92: 81-90, 2001.

CHENG JK, CHOU RC, HWANG LL, CHIOU LC: Antiallodynic effects of intrathecal orexins in a rat model of postoperative pain. J Pharmacol Exp Ther 307: 1065-1071, 2003.

DATE Y, MONDAL MS, MATSUKURA S, NAKAZATO M: Distribution of orexin-A and orexin-B (hypocretins) in the rat spinal cord. Neurosci Lett 288: 87-90, 2000.

FERGUSON AV, SAMSON WK: The orexin/hypocretin system: a critical regulator of neuroendocrine and autonomic function. Front Neuroendocrinol 24: 141-150, 2003. 
GRUDT TJ, VAN DEN POL AN, PERL ER: Hypocretin-2 (orexin-B) modulation of superficial dorsal horn activity in rat. J Physiol Lond 538: 517-525, 2002.

HERVIEU GJ, CLUDERAY JE, HARRISON DC, ROBERTS JC, LESLIE RA: Gene expression and protein distribution of the orexin-1 receptor in the rat brain and spinal cord. Neuroscience 103: 777-797, 2001.

HUANG LY, NEHER E: $\mathrm{Ca}^{2+}$-dependent exocytosis in the somata of dorsal root ganglion neurons. Neuron 17: 135$145,1996$.

KORCZYNSKI W, CEREGRZYN M, MATYJEK R, KATO I, KUWAHARA A, WOLINSKI J, ZABIELSKI R: Central and local (enteric) action of orexins. J Physiol Pharmacol 57 (Suppl 6): 17-42, 2006.

KUKKONEN JP, HOLMQVIST T, AMMOUN S, AKERMAN KE: Functions of the orexinergic/hypocretinergic system. Am J Physiol 283: C1567-C1591, 2002.

MARCUS JN, ASCHKENASI CJ, LEE CE, CHEMELLI RM, SAPER CB, YANAGISAWA M, ELMQUIST JK: Differential expression of orexin receptors 1 and 2 in the rat brain. $J$ Comp Neurol 435: 6-25, 2001.

MOBARAKEH JI, TAKAHASHI K, SAKURADA S, NISHINO S, WATANABE H, KATO M, YANAI K: Enhanced antinociception by intracerebroventricularly and intrathecally-administered orexin A and B (hypocretin-1 and -2) in mice. Peptides 26: 767-777, 2005a.

MOBARAKEH JI, TAKAHASHI K, SAKURADA S, NISHINO S, WATANABE H, KATO M, NAGHDI N, YANAI $\mathrm{K}$ : Enhanced antinociception by intracerebroventricularly administered orexin A in histamine $\mathrm{H}_{1}$ or $\mathrm{H}_{2}$ receptor gene knockout mice. Pain 118: 254-262, 2005 b.

OHNO K, SAKURAI T: Orexin neuronal circuitry: role in the regulation of sleep and wakefulness. Front Neuroendocrinol 29: 70-87, 2008.

SAKURAI T: The neural circuit of orexin (hypocretin): maintaining sleep and wakefulness. Nat Rev Neurosci 8: 171181, 2007.

SAKURAI T, AMEMIYA A, ISHII M, MATSUZAKI I, CHEMELLI RM, TANAKA H, WILLIAMS SC, RICHARDSON JA, KOZLOWSKI G.P, WILSON S, ARCH JR, BUCKINGHAM RE, HAYNES AC, CARR SA, ANNAN RS, MCNULTY DE, LIU WS, TERRETT JA, ELSHOURBAGY NA, BERGSMA DJ, YANAGISAWA M: Orexins and orexin receptors: a family of hypothalamic neuropeptides and G proteincoupled receptors that regulate feeding behavior. Cell 92: 573-585, 1998.

SUYAMA H, KAWAMOTO M, SHIRAISHI S, GAUS S, KAJIYAMA S, YUGE O: Analgesic effect of intrathecal administration of orexin on neuropathic pain in rats. In vivo 18: 119-123, 2004.

TRIVEDI P, YU H, MACNEIL DJ, VAN DER PLOEG LH, GUAN XM: Distribution of orexin receptor mRNA in the rat brain. FEBS Lett 438: 71-75, 1998.

VAN DEN POL AN: Hypothalamic hypocretin (orexin): robust innervation of the spinal cord. J Neurosci 19: 3171-3182, 1999.

VOISIN T, ROUET-BENZINEB P, REUTER N, LABURTHE M: Orexins and their receptors: structural aspects and role in peripheral tissues. Cell Mol Life Sci 60: 72-87, 2003.

WILLIS WD, WESTLUND KN: Neuroanatomy of the pain system and of the pathways that modulate pain. $J$ Clin Neurophysiol 14: 2-31, 1997.

XIA JX, CHEN XW, CHENG SY, HU ZA: Mechanisms of orexin A-evoked changes of intracellular calcium in primary cultured cortical neurons. Neuroreport 16: 783-786, 2005.

YAMAMOTO T, NOZAKI-TAGUCHI N, CHIBA T: Analgesic effect of intrathecally administered orexin-A in the rat formalin test and in the rat hot plate test. Br J Pharmacol 137: 170-176, 2002.

YAMAMOTO T, SAITO O, SHONO K, HIRASAWA S: Activation of spinal orexin-1 receptor produces anti-allodynic effect in the rat carrageenan test. Eur J Pharmacol 481: 175-180, 2003 a.

YAMAMOTO T, SAITO O, SHONO K, AOE T, CHIBA T: Anti-mechanical allodynic effect of intrathecal and intracerebroventricular injection of orexin-A in the rat neuropathic pain model. Neurosci Lett 347: 183-186, $2003 \mathrm{~b}$.

YANG B, SAMSON WK, FERGUSON AV: Excitatory effects of orexin-A on nucleus tractus solitarius neurons are mediated by phospholipase $C$ and protein kinase C. J Neurosci 23: 6215-6222, 2003.

ZHANG C, ZHOU Z: $\mathrm{Ca}^{2+}$-independent but voltage-dependent secretion in mammalian dorsal root ganglion neurons. Nat Neurosci 5: 425-430, 2002.

ZHANG X, BAO L: The development and modulation of nociceptive circuitry. Curr Opin Neurobiol 16: 460-466, 2006. 